Article

\title{
Governing a Sustainable Business Ecosystem in Taiwan's Circular Economy: The Story of Spring Pool Glass
}

\author{
Ying-Che Hsieh ${ }^{1, *}$, Kuo-Yi Lin ${ }^{2}$, Chao Lu ${ }^{3}$ and Ke Rong ${ }^{4}$ \\ 1 Institute of Technology Management, National Tsing Hua University, 101, Sec. 2, Kuang-Fu Road, \\ Hsinchu City 30013, Taiwan \\ 2 Department of Business Administration, Asia University, 500, Liufeng Road, Wufeng Dist., \\ Taichung City 41354, Taiwan; kylin@asia.edu.tw \\ 3 School of Management, Shanghai University, 99, Shangda Road, Shanghai 200444, China; chaolu@shu.edu.cn \\ 4 Institute of Economics, School of Social Science, Tsinghua University, Beijing 100084, China; \\ r@mail.tsinghua.edu.cn \\ * Correspondence: ych@mx.nthu.edu.tw; Tel.: +886-3-574-2417
}

Received: 8 May 2017; Accepted: 16 June 2017; Published: 20 June 2017

\begin{abstract}
The business ecosystem has provided a new paradigm for management research. Most research in the field has focused on profit-driven industries, neglecting the area of the circular economy. This research sets out to capture the mechanisms that the leading firm in the circular economy uses to govern its business ecosystem. The research strategy adopted is a longitudinal case study of the largest glass recycling company in Taiwan, Spring Pool Glass. Our findings illustrate that continuous value capture is the key to governing a sustainable business ecosystem in the glass recycling industry. The mechanisms include continuous value capture to enter new markets, using stakeholder networks to enlarge the business ecosystem, brand image and corporate social responsibility, company capabilities and research and development in the recycling process, and reacting to government policy.
\end{abstract}

Keywords: business ecosystem; circular economy; Taiwan; glass recycling

\section{Introduction}

The concept of the ecosystem provides a systemic way to describe social systems via the business ecosystem [1], platform ecosystem (mainly information technology based research) [2,3], innovation ecosystem [4-6], and entrepreneurial ecosystem [7] and thereby to extract theories of complementary invention and develop indirect network effects. It offers researchers a new concept with which to capture the complexity and dynamic nature of modern industrial systems [8]. Researchers have used this concept to capture new phenomena that could not be fully explained by previous theories (e.g., Shanzhai cellphones, the ARM versus the Intel ecosystem). As the actors to be considered in investigating new phenomena these days may be dispersed across different firms, industries, or even countries, previous concepts such as subcontracting or supply chains may not be sufficient to portray the whole picture [8].

Business ecosystem research has now been carried out in many areas such as strategic management, innovation, operations management, and others. Most of the current research has focused on the economic value created by the business ecosystem. For example, Li's research claimed that the services, tools, or technologies shared in a platform ecosystem could enhance the performance of its members [9]. However, little research has focused on how the operations of a business ecosystem could have a positive impact on our environment (overall sustainability). As global 
and regional environmental initiatives have started to emphasize environmental protection, more and more countries and international organizations have begun to recognize the importance of waste management, recycling, reuse, and sustainable development. We feel there is a chance and also a 'need' to develop a new stream of business ecosystem research linked to the circular economy, with the aim of contributing to the knowledge of how a leading firm might lead a 'good' and 'sustainable' ecosystem, in order to maintain both business and environmental value at the same time.

The concept of the circular economy has prospered in recent years, covering the ideas of industrial symbiosis and extended product life [10]. The manufacturing operations, delivery processes, and waste management of companies have also become significant factors in the consumer's purchasing decision. In turn, scholars, governments, and industry have started to pay great attention to this area, embracing the idea of the green economy. Recently, this trend has also swept Taiwan. According to The Wall Street Journal, in the past, Taiwan was known as 'the garbage island', but it has now become a model of resource recycling [11]. This huge transformation has necessitated numerous industries to change their old processing patterns.

In the development of industry, Taiwan plays an important role from glass products to high-tech products and from material extracting to manufacturing. In terms of discarded glass bottles, the average annual volume of recycling in 2014 and 2015 had reached 227 thousand tons [12]. Moreover, about six thousand tons of waste liquid crystal display (LCD) are discarded each year due to the growth of the optoelectronic and high-tech industries [13]. Such waste glass can cause unpredictable contamination of landfill, incineration, or composting processes. Hence, the treatment of waste glass should be moving in the direction of the recovery and reuse of LCD. The recycling of glass can help to reduce resource consumption, waste, the use of energy, and air and water pollution. Glass recycling industries are being taken more seriously by global policy and environmental trends. However, they face problems in the form of uncertainty about market needs and low profit margins.

Hence, this study seeks to investigate the largest glass recycling firm in Taiwan, Spring Pool Glass, in the hope of learning from their experience of governing their business ecosystem under the circular economy, which has demonstrated both economic and environmental value, in the Asian context.

\section{Literature Review}

\subsection{Business Ecosystem Research}

The business ecosystem is a concept that is currently seeing a boom in terms of the number of scholars using it to provide a perspective on business communities. The concept takes the analogy of biology, in which random collections of elements tend to gradually form a more structured community [1,14]. The business ecosystem concept moves beyond the view of traditional market positioning and industrial structure, positing instead three major characteristics: symbiosis, platform and co-evolution [9]. As the ecosystem matures, its leading firms should pursue strategies not only in their own interests [15] but also to improve the overall health of their ecosystem [16]. Since Moore [1] first proposed the concept, four streams of research have emerged and contributed to the body of knowledge on business ecosystems [17].

\subsubsection{Business Ecosystem}

The first stream of research was inspired by the work of Moore proposing the concept of the business ecosystem and its lifecycle [1]. He claimed that every business ecosystem will go through four distinct stages: birth, expansion, leadership, and self-renewal/death. At the birth stage, firms will capture value around a certain innovation by working with their customers and suppliers. At the expansion stage, firms will expand into a larger market by cooperating with suppliers and partners, seeking to maximize market share. At the leadership stage, the leading firm will provide a vision for the future so that the stakeholders will be guided and encouraged to work together. At the self-renewal stage, the challenge is to work with new ecosystems or innovations that emerge from the existing 
ecosystem. The lifecycle approach provides scholars with a valid framework through which to analyze the evolution of major businesses. Moore provided cases from the retail and automobile industries to demonstrate his lifecycle approach [1]. Rong et al. also used the lifecycle approach to analyze the platform strategy within the semiconductor industry [17].

The Cambridge Group extended business ecosystem research by proposing a 6C framework [18] and a schema for regional ecosystems [7]. Rong et al. [18] proposed the 6C framework, comprised of context, construct, configuration, cooperation, capability, and change, based on their research in Internet-of-Things-based sectors. They argued that the $6 \mathrm{C}$ framework was useful for understanding the complex network system that forms the business ecosystem. The context dimension looks at how firms' missions, drivers, and barriers change at different stages of the lifecycle. The construct dimension, namely the 'structure-infrastructure' framework commonly used in manufacturing systems and supply-chain management, defines the fundamental structure and supportive infrastructure in the ecosystem. The configuration dimension defines the configuration patterns and external relationships among partners in the ecosystem. The cooperation dimension illustrates the mechanisms by which partners interact with each other to achieve common goals. The capability dimension reflects the key success factors of a supply network such as communication and accessibility, integration and synergy, learning ability, and adaptation and mobility. The change dimension seeks to identify how system configuration patterns shift over time. Overall, the 6C framework provided a whole-system architecture with which to study networks from a more comprehensive perspective [18].

Another model proposed by the Cambridge Group was a schema for regional ecosystems [7], which takes a geographic perspective. Researchers have started to realize that there are regional impacts on value creation and technology transfer in the ecosystem [19]. The Cambridge Group's conceptual model illustrated that startups would access the resource pool in social networks embedded in a particular region. These resources might be human resources such as fresh graduates and skilled workforces and institutions such as venture capitalists or local infrastructure. Then the value creation process would transform the local resources embedded in the social network into value networks. Finally, the value network would create a feedback loop back to the local resource pool, accompanied by the clustering of manufacturing industries in a certain region. Their work provided a different perspective on business ecosystems in a geographic regional setting.

\subsubsection{Platform Ecosystem}

The second stream of research has enriched the knowledge of business ecosystems by introducing the concept of the platform ecosystem. Iansiti and Levien stated the importance of a platform strategy for a keystone firm wishing to create its ecosystem [16]. The platform could be a physical set such as the 'efficient manufacturing capabilities that Taiwan semiconductor manufacturing offers to computer-chip design companies that don't have their foundries' or an intellectual asset such as Windows software [16] (p. 7). Rong et al. argued that the platform was a critical element of the value creation process, acting as a business ecosystem's interaction interface [17]. The services, tools, and technologies provided by the platform would also enable the members of the ecosystem to enhance their performance [9]. Gawer and Cusumano later identified two types of platform, internal or company-specific and external or industry-wide [20]. Internal (company or product) platforms offer the firm itself or its suppliers the opportunity to build products or features by sharing reusable components or technologies. External (industry) platforms allow large numbers of firms to 'open' and share their products, services, or technologies to achieve a network effect that boosts innovation. Gawer and Cusumano also identified practices for platform leaders to use to effectively manage platform competition and innovation [20].

\subsubsection{Innovation Ecosystem}

The third stream focuses on the innovation ecosystem [21]. In the key paper in this stream [4] (p. 98), Adner defines the innovation ecosystem as 'the collaborative arrangements through which firms 
combine their individual offerings into a coherent, customer-facing solution'. Adner's work provides a different angle for looking at how firms should develop their innovation strategy while considering three fundamental risks. Researchers have also identified how external innovators influence the focal firm's (technology leader's) new innovation. Adner and Kapoor found that the 'location' of the external innovators could either enhance or erode the focal firm's technology leadership [22]. Later, Adner and Kapoor developed a framework considering focal competing technologies and the innovation ecosystem in which they were embedded [23]. Their results identified four distinct regimes predicting the pace of substitution of technology.

\subsubsection{Entrepreneurial Ecosystem}

The fourth stream focuses on the entrepreneurial ecosystem by taking the perspective of ecosystem entrepreneurs, investigating how entrepreneurs should align their vision, goals, and structures with those of the ecosystem leader [24]. This stream of research provides a different perspective from that focusing on a leading firm (keystone firm, focal firm, platform leader, or hub firm) to look at the context (entrepreneurial ecosystem) in which the new startup is embedded. Previous research has focused on how entrepreneurs may go through a self-regulatory process to successfully manage challenges in an ecosystem [24].

\subsubsection{Research Gap Identification}

Based on our literature review, research on business ecosystems has prospered since Moore introduced the concept [1]. Scholars have tried to link different bodies of knowledge to contribute to business ecosystem research such as operations management [25], entrepreneurship [24], strategy [26], and innovation [20]. Most research has focused on how leading firms should manage their ecosystems (including platform and innovation ecosystems) to retain their competitive advantage or, on the other hand, how startup companies should deal with the ecosystems in which they are embedded (entrepreneurial ecosystems). Current research is focusing on how firms could benefit from the ecosystem network to achieve better business performance. However, little research has focused on how the leading firms or startups might manipulate the ecosystems in which they are embedded to achieve both environmental and business goals at the same time. Hence, this research aims to answer this question, taking an alternative perspective on firms and their ecosystems as a sustainability mechanism. In order to answer this question, the literature on the circular economy was also reviewed, with the purpose of linking business ecosystems and the circular economy.

Furthermore, in terms of the research context, we also found that most empirical research to date has focused on industries such as information technology $[20,25,27,28]$ and automobile manufacturing [1,29]. Little research has focused on less profitable industries such as the recycling business. Hence, this research is also aimed at covering this neglected area. Finally, although some empirical research has been conducted in the Asian context [25,29], mainly on the semiconductor industry, little of it has emphasized how the Asian context influences the ecosystem in which the firms are embedded. Hence, with this research we would also like to put more focus on that aspect.

\subsection{Circular Economy}

The central concept of a circular economy is the 'valuation of materials within a closed-looped system with the aim to allow for natural resource use while reducing pollution or avoiding resource constraints and sustaining economic growth' [30] (p. 825). The circular economy aims to provide a better alternative to the 'take, make and dispose' [31] dominant economic development model, leading to more sustainable development and a symbiotic ecosystem. Sustainable development requires balanced and simultaneous consideration of the economic, environmental, technological, industrial, and social aspects of a given economy or sector. The negative effects of the dominant economic development model threaten the stability of economies and the integrity of natural ecosystems that are essential for humanity's survival [32]. 
Research on the circular economy has focused on three streams [30]. The first stream is policy instruments and approaches. Research in this stream covers the topics of eco-industrial parks, eco-industrial networks, and industrial symbiosis. It views the circular economy within a regional setting, taking a government perspective to analyze how different countries have inspired and supported eco-industrial parks. Governments are also actively moving towards a recycling economy by converting waste into renewable resources through the circular economy's business model.

The second stream has focused on the value chain, material flows, and products. It looks at how materials are managed or reused through the value chain, covering wood and paper, plastics, metals, phosphorus and other chemicals, water, etc. It has gradually increased its scope from narrow waste to extensive economic orientation control, especially in the closed stages of the raw material cycle, including production, distribution, consumption, and other steps [33]. The aim is to restore and stabilize waste in such a way as to allow the supply chain to reuse raw materials repeatedly, creating a circular economy. The three criteria of reduction, reuse, and recycle have been applied in materials and energy areas [34]. National governments, industry, and other mainstream areas focus on product design trends, the supply chain, the manufacturing process, and usage for sustainable development.

The third stream looks at technological, organizational, and social innovation. This stream has sought to link circular economy research to business-oriented research. As most research on the circular economy is technical and economical, this has led to a lack of stakeholder involvement and a lack of shared vision [30]. The existing research has put emphasis on the interaction of process and planning design $[10,33]$. The structure and interaction of process and planning that exist in the communication system model and frame the actions of firms, highlighting the importance of the interrelationships between multiple organizations and how this interaction could represent sustainable product-service solutions as an important source of competitive advantage and the circular economy. The way that circular economy agents interact is drawing more attention, offering a great opportunity to link the circular economy to the business ecosystem literature.

Our review has illustrated that research on the circular economy has gradually expanded from government policy to the management of the value chain and material flows and now to a more business-oriented perspective. On the other hand, in the business ecosystem literature, research has mainly focused on the network of various stakeholders and how it achieves economic value. The two bodies of knowledge, initially unrelated, seem to have coincided as both have started to expand. We believe this offers a good opportunity to investigate a new research area of how different stakeholders could work in a more systematic way to achieve both environmental and business goals at the same time, thereby ensuring overall sustainability.

\section{Materials and Methods}

\subsection{Research Setting}

We adopted a longitudinal case study approach [35] in this research by applying the evolutionary stages of a business ecosystem [1] to observe how the sampled firm built up its business ecosystem in the Asian context. This research sought to identify how the firm had developed over time to build up its social networks and how these networks help the leading firm (i.e., the sampled firm) to govern its business ecosystems.

We selected the glass recycling industry as the research target for two reasons. First, Taiwan is famous for its high-technology industry, and every year the industrial glass waste (e.g., LCD) and household glass waste consists of around 223 thousand tons in total [12,13]. Industrial glass waste such as plate glass like LCD can seriously pollute the environment unless treated properly [36]. Second, of all the recycling industries, the glass recycling industry's profit margin is among the lowest. As glass is $100 \%$ recyclable and can be recycled repeatedly with no loss in purity or quality, investigating the glass recycling industry would be beneficial since its development should be representative of the development of the recycling business as a whole. The glass recycling rate in Taiwan is around 
92.1\% [37], while the overall recycling rate is 55\% [11], placing Taiwan's recycling rates among the highest worldwide. Thus, Taiwan represents the 'best practice' of the glass recycling industry globally. The results could be beneficial for other glass recycling ecosystems wishing to emulate Taiwan's success. Hence, we believe that studying the leading firm in the glass recycling industry in Taiwan will contribute greatly to the knowledge of both business ecosystems and the circular economy.

We adopted a single case study approach, focused on the leading firm in Taiwan's glass recycling industry. Whether single or multiple cases generate better theory has been rigorously discussed. Eisenhardt argued that multiple cases were a powerful means of creating theory because they permit replication and extension [38]. However, Dyer and Wilkins claimed that a single case study was able to capture a more in-depth and richer background [39]. The 'optimal' number of cases is still a question of academic debate and strongly 'depends on how much is known and how much new information is likely to be learned from incremental cases' [38] (p. 622).

We selected the leading glass recycling company in Taiwan, Spring Pool Glass, as our main case. Spring Pool Glass has a market share of over 70\% in Taiwan's glass recycling industry (including both industrial and household recycling). As of January 2017, it had 120 employees, five factories, 30 logistic cars (capacity per car above 35 tons), and 30 points of sale (for recycled glass artwork). Its main business covers glass recycling, an industrial tourism factory (a working factory that tourists can visit to observe the work carried out and purchase artwork), recycled-glass building materials, and recycled artistic glass (use in works of art). The business coverage of Spring Pool Glass in the circular economy is presented in Figure 1.

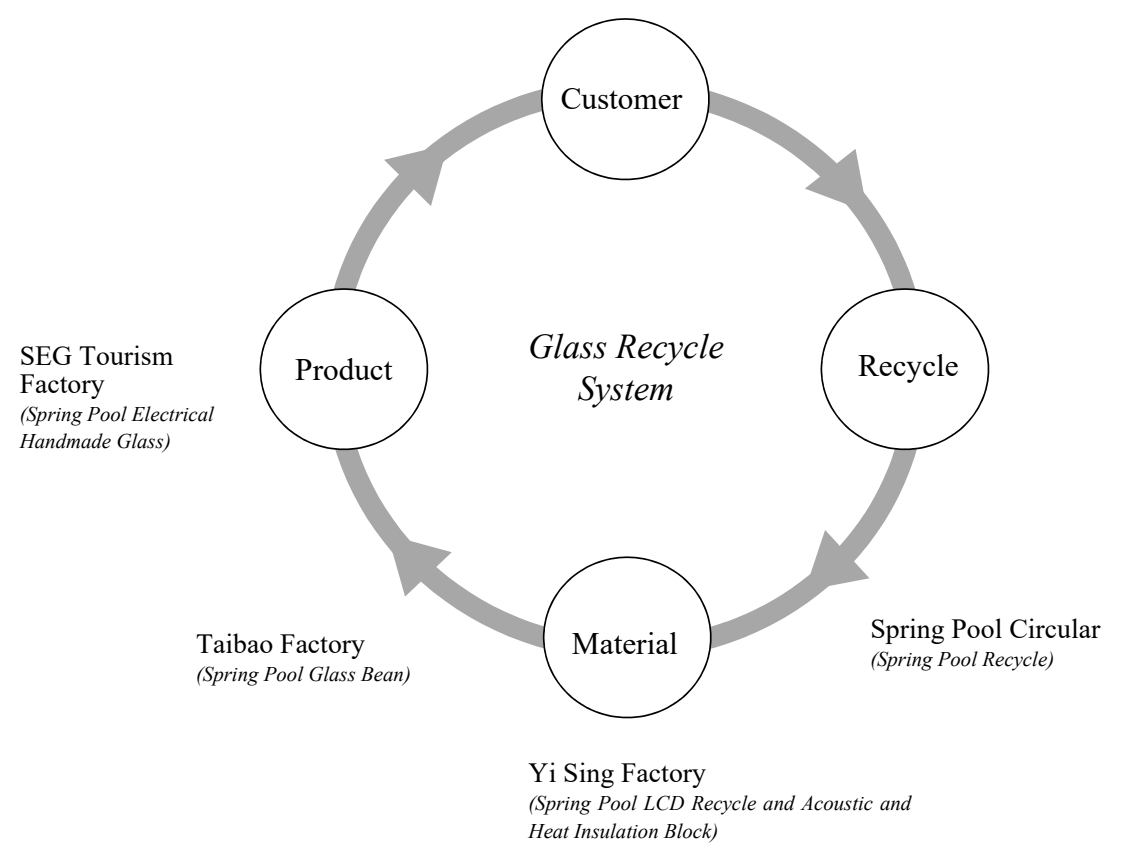

Figure 1. Spring Pool Glass in a circular economy.

\subsection{Data Collection and Analysis}

To investigate the mechanisms of how Spring Pool Glass governs its ecosystem and how it has interacted with other stakeholders over time, we adopted the grounded theory method in this research $[35,40]$. We started by identifying the key events so as to match them with the evolutionary stages of the business ecosystem [1]. Next, we followed the evolutionary stages to see how Spring Pool Glass managed its social networks and how these relationships had contributed to its growth.

The main data collection methods used in this research were semi-structured interviews, archival data, and direct observation (several site visits). Each interview lasted from one to three hours, and all were recorded and transcribed for analysis (Appendix A). We obtained data on aspects such 
as the organization's history, business models, public reports in the press, campaigns, and future development plans and also from their website and Facebook fan pages. Then, the data were analyzed through a coding process consisting of three steps. First, the text of each individual interview was screened to get an overall understanding of the conversation. Next, each interview record was divided into different categories, and the relationships between the categories were analyzed in order to clarify the interactions of different stakeholders and the development of the glass recycling ecosystem. In the third step, these broad categories were subdivided into smaller categories, and findings that went beyond the original research objectives were separated out. This process refined the specific research objectives to be explored in the sample firm. A comparison was made across the multiple interviews, helping the author to gain a better understanding of how Spring Pool Glass governed its ecosystem. Potential biases or errors were also identified at this stage, based on any conflicts or inconsistencies between different respondents. At the same time, the secondary data were also categorized and analyzed. This supported the main results and protects against bias.

\section{Case Study}

This section will present the case based on the lifecycle of the business ecosystem to demonstrate how Spring Pool Glass captures value and builds up its social networks. This section will also present the story of Spring Pool Glass from a different perspective. In the birth and expansion stages, we will focus on how the entrepreneur built up the firm's social network and captured value within the ecosystem. In the leadership stage, we will focus on how the company governs its ecosystem. The development of Spring Pool Glass's ecosystem is presented in Figure 2.

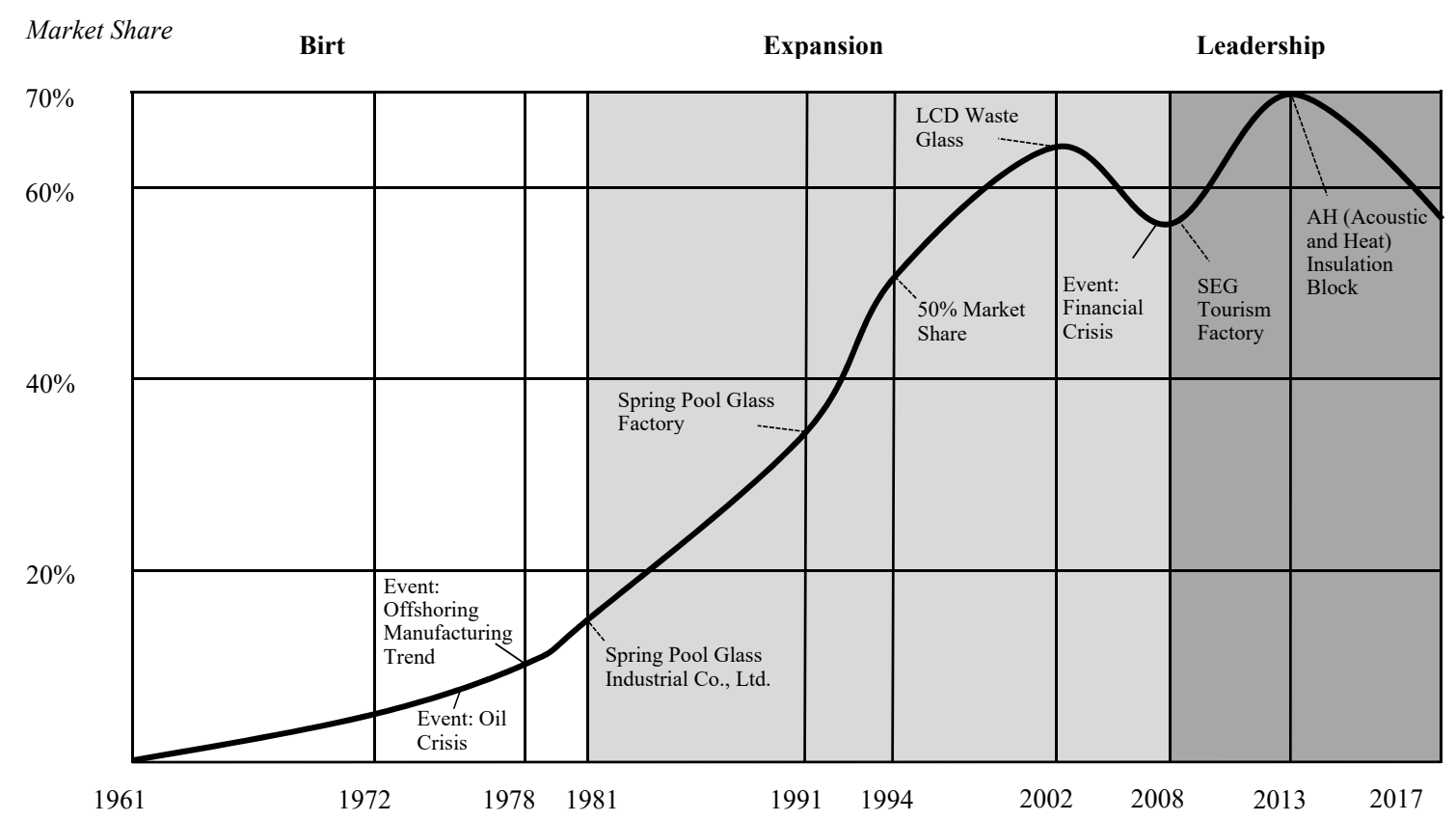

Figure 2. Development of Spring Pool Glass's ecosystem.

\subsection{Birth Stage: $1972-1980$}

Before Mr. Wu started Spring Pool Glass in 1972, he had been working in the glass manufacturing industry since his graduation from elementary school in 1961. Initially he joined the Hsinchu Glass Factory to obtain basic knowledge of glass manufacturing. Two years later, he was transferred to the China Glass Industrial Research Institute, a research institute sponsored by the Hsinchu Glass Factory, to learn how to melt glass, mix colors, and make glass artwork. From 1969 to 1972, Mr. Wu served in the military so as to fulfill the mandatory military service required by the Taiwan government. 
After Mr. Wu resigned from the military in 1972, he decided to start his own business in the glass recycling industry, sensing its potential. At that time, the industry was dominated by small recyclers. Recyclers would gather waste glass from households (the recycler did not have to pay for this) or factories (over a certain amount of waste glass, these recyclers did have to pay) and sell it to glass manufacturers as an input. Mr. Wu started his business as a self-employed individual, carrying waste glass, mainly cathode ray tube (CRT) monitors and waste glass bottles, with his own scooter and crushing the waste glass in his own backyard. Due to his previous experience and contacts in the glass industry, his initial sales strategy was to provide high-quality recycled glass to small factories so as to build a good reputation.

Next, to enlarge his glass supply, Mr. Wu also started to collect waste glass from other counties and bought a second-hand truck to increase his capacity. However, local factions from other counties were a big challenge to Mr. Wu's attempts to collect waste glass. He later resolved this problem by using the contacts he had made during his military service and a former colleague from the Hsinchu Glass Factory.

In 1975, when the 'Taiwan Economic Miracle' started to boom, the market for waste glass was seen as having a bright future due to the oil crisis. Hence, Mr. Wu bought his first land to use to stack waste glass $\left(2000 \mathrm{~m}^{2}\right)$. During the same period, $\mathrm{Mr}$. Wu also owned his own fleet of trucks, helping him to secure his waste glass supply. However, in 1978, the glass industry in Taiwan went through a depression due to the trend of offshoring manufacturing. Glass factories were not buying waste glass due to the shortage of demand. In order to stack his oversupply of waste glass, Mr. Wu was forced to buy another plot of land in 1978 (this time 10,000 $\mathrm{m}^{2}$ in size). However, this investment later became a great advantage for his company, while there was a high entry barrier for latecomers to the industry.

\subsection{Expansion Stage: $1981-2008$}

In 1981, Mr. Wu established Spring Pool Glass Industrial Co., Ltd. (Hsinchu, Taiwan), to transform his business from a home-run operation to a more structured setting. The company also introduced new automatic machines to classify and smash the waste glass, dramatically increasing its capacity to deal with waste glass from 1 to 50 tons per hour. Overall, in this stage, Spring Pool Glass enlarged its ecosystem on both the demand and the supply side. On the supply side, due to its long-term collaboration with waste glass suppliers, mainly family-based, Spring Pool Glass started to dominate the glass recycling business. On the demand side, due to the increase in its capabilities, Spring Pool Glass was also able to sell these recycled materials (glass) to large factories for manufacturing use. At the time, recycled glass was classified into three different levels according to its quality. The first class was sent to glass factories for manufacturing, the second class was used in ceramics, and the third as a material in cement making.

However, by 1991, nearly $90 \%$ of the glass manufacturing industry had migrated to Mainland China or Southeast Asia. Most of Spring Pool Glass's competitors (in the glass recycling business) had left the Taiwanese market, and many of those that stayed had changed their commercial land-use permits and hence left the glass recycling business. This trend provided Spring Pool Glass with an opportunity to expand its market share. However, at the same time, due to the lack of demand (the migration of glass manufacturing firms), Spring Pool Glass started to invest in research and development (R\&D) to search for new channels that might consume its recycled glass. In 1999, Spring Pool Glass invented new technology that remakes recycled glass into an eco-friendly building material, the 'glass bean', which later become a high-value-added product. Moreover, at this stage, Spring Pool Glass also gained the ability to analyze the composition of its waste glass on a more scientific basis, which increased its capability for dealing with waste glass.

During this time, the electronics industry started to prosper in Taiwan. A lot of industrial glass waste was produced such as LCD, flat glass, fiber glass, container glass, and sodium silicate glass. Most of the glass manufacturing firms lacked the knowledge to deal with this glass waste as the composition was different from the glass recycled previously. In order to consume this industrial waste 
glass from the electronics industry, Spring Pool Glass invested more in R\&D, seeking opportunities to transform such glass into standalone products. In 2002, Spring Pool Glass cooperated with Company A, the largest manufacturer of LCD glass, ceramics, and related materials, primarily for industrial and scientific applications. Spring Pool Glass purchased Company A's waste LCD glass and transformed it for use in ceramics and to make cement aggregate. Spring Pool Glass also began to export some recycled glass that was not suitable for Taiwan's manufacturers to its foreign partners.

In 1997, the Taiwanese government implemented a new policy, the 'four-in-one resource recycling project', seeking to build a complete recycling system in Taiwan. This act brought Spring Pool Glass both advantages and disadvantages. The main advantage was that, due to the government promotion, the overall recycling rate increased. With the involvement of cleaning teams and recyclers, Spring Pool Glass is saved the effort of collecting waste glass with its own fleet of trucks. However, the main disadvantage stemmed from the resulting transparency of the recycling market. All waste glass collected by the cleaning team and recyclers now had a 'price' and competitors had to bid to obtain it from the government. To win the bid, Spring Pool Glass had to pay a slightly higher price than it had done previously. Moreover, one of Spring Pool Glass's strengths, its stakeholder network (for waste glass collection), was limited after the launch of this project.

By the end of the expansion stage, Spring Pool Glass was processing more than $50 \%$ of all glass recycling in Taiwan, making it a leading firm in the glass recycling ecosystem. Two main factors enabled Spring Pool Glass to maintain its advantage. First, it had achieved an economic scale that produced a profit. As glass recycling is a very low-margin business, firms need to achieve a certain scale in order to generate a profit. Second, its competitors faced high barriers to entry. Spring Pool Glass had continually aligned its recycling technology with changes in the country's development. As glass products changed over time (e.g., from household glass waste to LCD waste), Spring Pool Glass was always learning and researching how to recycle the latest waste glass. Any new firm would have to gain this knowledge in order to compete.

\subsection{Leadership Stage: 2008 to Present}

In 2008, Spring Pool Glass established a brand for its own recycled-glass artwork called SEG (Spring Pool Electrical Handmade Glass). It recruited many senior glass artisans to craft handmade art pieces in its industrial tourism site in Hsinchu. It also established 11 selling points for these recycled art pieces across Taiwan. The purpose was to promote its own branding and inherit Hsinchu City's glass culture and in turn promote its corporate social responsibility (CSR) and make citizens aware of the importance of recycling. Moreover, in 2013, through its own R\&D, Spring Pool Glass developed 'an insulation block' from recycled glass, which has excellent soundproofing and heat prevention qualities. This new product has since been used as a building material in the construction industry, bringing higher margins than before.

Since Spring Pool Glass is the leading firm in the glass-recycling ecosystem in Taiwan, there are mechanisms that govern its ecosystem, involving different stakeholders. From the supply side, Spring Pool Glass collects waste glass from households and industrial manufacturing. The household waste glass comes from two channels: first, the cleaning team and recyclers in collaboration with the government (the four-in-one resource recycling project), and second its long-term collaboration with individual recyclers. In the case of industrial glass waste, Spring Pool Glass collects from LCD factories and glass manufacturers. The main reasons these big factories are willing to provide waste glass to Spring Pool Glass are (1) it pays an adequate price, (2) the large amount of land and technology required to deal with industrial glass waste, and (3) Spring Pool Glass's long-standing good reputation and its CSR campaign promoted through its industrial tourism factory.

From the demand side, Spring Pool Glass is providing recycled materials to manufacturing firms in different industries such as ceramics, asphalt, cement, and glass manufacturing. Glass manufacturers have great incentives to buy recycled materials from Spring Pool Glass due to the subsidies they can receive by participating in the four-in-one resource recycling project. At the same time, Spring Pool 
Glass is also selling products directly to end customers. It produces three main products from its recycled glass: (1) artistic glass manufactured in its industrial tourism factory, (2) 'glass beans' used for paving roads and walls, and (3) 'insulation blocks' used as a construction material.

In addition to its supply and demand advantages, Spring Pool Glass is the only company to have joined commercial associations for both the glass manufacturing and glass recycling industries such as the Taiwan Glass Commercial Association, Hsinchu Glass Commercial Association, and Taiwan Resource Recycling Industries Association. This has enlarged Spring Pool Glass's social network, enabling it to capture value more quickly than its competitors.

In sum, as of 2017, Spring Pool Glass dealt with 70\% of the recycled glass in Taiwan. $70 \%$ of its revenue comes from selling recycled materials for reuse, mainly in glass manufacturing, ceramics, asphalt, and cement. $20 \%$ of its revenue comes from its sales of building materials, namely the glass bean and the insulation block. $10 \%$ of its revenue comes from selling recycled-glass artwork. The corporate image of Spring Pool Glass is that of providing high-quality recycled glass at a reasonable price. The social network of its founder, $\mathrm{Mr}$. Wu, and the company's ability to capture value have enabled it to become and remain the leading firm in the glass-recycling ecosystem in Taiwan. The recycling ecosystem of Spring Pool Glass is presented in Figure 3.

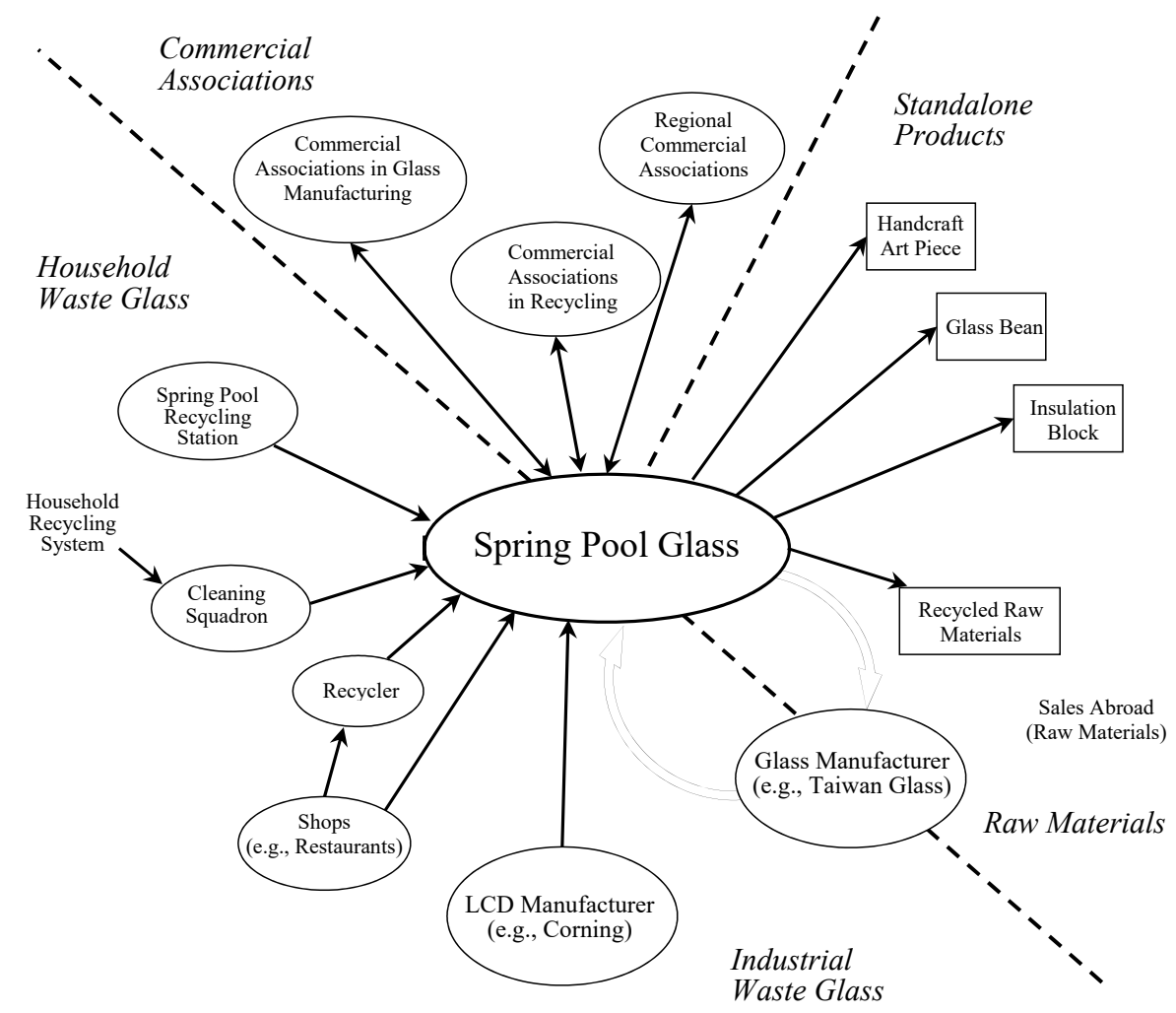

Figure 3. Spring Pool Glass recycling ecosystem in Taiwan.

\section{Discussion}

Our research illustrates that continuous value capture is the key to governing a sustainable business ecosystem. Through the case analysis of Spring Pool Glass, we identified five elements of continuous value capture in the glass recycling business.

\subsection{Continuous Value Capture to Enter New Markets}

Continuous value capture by the leading firm in this circular economy is critical for several reasons. First, the demand and supply of the waste glass industry is unbalanced most of the time. Spring Pool Glass needs to search continually for new uses for its recycled materials, and for new 
uses for different sources of waste glass. For example, recycled LCD glass is turned into insulation blocks, glass products are turned into glass beans, and other recycled materials that Taiwan's market cannot consume are exported. These value-capturing activities bring innovative ways of transforming the recycled glass into new products, which brings high value/margins for the company. Second, through the value-capturing activity, the leading firm will play the lead role in joining with other ecosystems to create new business models. For example, Spring Pool Glass has joined the electronics manufacturing ecosystem to recycle its waste LCD glass. Also, by remodeling waste glass, Spring Pool Glass participates in the artwork ecosystem, selling its recycled art pieces. In the recycling business (as a part of the circular economy), continuous value capture, as a mechanism for linking the ecosystem to other ecosystems to create higher margins, is very important.

Balancing and maintaining the proper margins of different stakeholders to retain the overall health of the ecosystem is also critical [41]. As the margins in the glass recycling business in Taiwan are very low, it is critical that the leading firm supports some of the stakeholders such as individual recyclers and cleaning teams so as to secure the ecosystem.

\subsection{Importance of Stakeholder Networks for Enlarging the Business Ecosystem}

We have also observed the impact of the entrepreneur's personal network on the value network, which in turn enlarges its business ecosystem. This echoes the view of Shi and Shi [7]. The business story of the founder of Spring Pool Glass shows that his personal network has impacted the business throughout the different lifecycles of the business ecosystem. In the birth stage, Mr. Wu's experience in the Hsinchu Glass Factory and his mandatory military service supported his business expansion by helping him to deal with glass manufacturers and local factions. In the expansion stage, due to the company's long-term collaboration with individual restaurants and recyclers, the stable supply of waste glass supported its continued growth. In the leadership stage, its cumulated stakeholder network, such as the trust built up with different stakeholders, connections to different companies through commercial associations, and its relationship with the local government, has helped Spring Pool Glass to govern the business ecosystem.

The stakeholder network has also influenced the profit making of Spring Pool Glass. As the supply of waste glass has become market-oriented, for example requiring the purchase of waste glass from LCD factories, glass manufacturing factories, and the government's cleaning team, its good relationships within its stakeholder network has enabled Spring Pool Glass to continue collecting waste glass for free with its own fleet of trucks.

\subsection{Brand Image and CSR}

In the recycling industry, brand image and CSR activities are observed to bring positive benefits to firms. This is especially important now that the concept of sustainability has become a trend in the Asian countries. Spring Pool Glass has started to promote its brand and CSR since becoming the leading firm in the ecosystem. Its industrial tourism site has become a very important marketing channel, giving it impact and recognition among the Taiwanese citizens, which has also strengthened its social network. The art pieces crafted at the industrial tourism site are also being sold in several stores across Taiwan, emphasizing its efforts to turn waste glass into art. Moreover, Spring Pool Glass has also cooperated with universities, attending several green building competitions and providing its recycled building materials. These promotions have positioned Spring Pool Glass as not only a glass recycling company, but a pioneer in the recycling business, looking to fulfill its social responsibility.

Moreover, the overall image and CSR of Spring Pool Glass have also influenced the willingness of foreign companies to collaborate with it. For example, Company A is willing to provide its waste LCD glass to Spring Pool Glass in part because of the latter's overall good image. The story of Spring Pool Glass has illustrated that, even in the circular economy, brand promotion and CSR are important mechanisms for maintaining relationships with stakeholders as the trend of sustainability is influencing Asian countries. 


\subsection{Company Capabilities and RED in the Recycling Process}

The capabilities a company requires in order to perform the recycling process are critical for the leading firm. The core capability of Spring Pool Glass is that it has been able to maintain low costs and high quality during the recycling process, mainly because it has its own fleet of trucks and because of the efficiency of its factory processing. In addition, the land that Spring Pool Glass has bought has allowed it to provide land piling to subsidiary companies and factories. This has helped the entire glass cluster to perform better, controlling quality and delivery dates. In terms of innovation and learning ability, Spring Pool Glass cooperates with institutes, other companies, and universities, as well as engaging in continuous $R \& D$ to support value-capturing activities. Continuous $R \& D$ is also very important for enhancing its own capabilities. For example, Spring Pool Glass has developed its own automatic glass-crushing machine, the ability to conduct composition analysis when recycling glass, the 'insulation block' generated from recycled LCD and glass, and the 'glass bean' generated from recycled glass. Overall, the capabilities of the leading firm are very important in the circular economy. Spring Pool Glass's main capabilities are the efficiency of its factory processing, its fleet of trucks, its $R \& D$, and its land.

\subsection{Reacting to Government Policy regarding the Circular Economy}

Government institutions will also affect how leading firms govern their ecosystems. In Taiwan, the government's four-in-one resource recycling project had an impact on the glass recycling ecosystem by changing the rules within it. It led to citizens in the community, a cleaning squadron, recyclers, and a recycling fund combining to ensure garbage was recycled and reused. This mechanism also ensured that stakeholders in the system gained a reasonable profit.

During the policy shaping process, Spring Pool Glass was highly involved as a keystone firm representing the glass recycling industry. From the government's point of view, one of the key elements required in order for the four-in-one resource recycling project to succeed was recycling logistics and processing. As these are the key advantages of Spring Pool Glass (it has its own fleet of trucks, strong capabilities in the recycling process, and various production lines), its commitment to and participation in this project is very important.

The four-in-one resource recycling project also imposed two major changes on the way Spring Pool Glass governed its ecosystem. First, due to the government's efforts to collect household waste, Spring Pool Glass was able to cut down on its own efforts in this regard. However, Spring Pool Glass now had to bid for the government-collected waste glass. This change decreased its previous advantage of having close connections with households and recyclers (social network), but at the same time increased its supply of waste glass. It also brought about another challenge for Spring Pool Glass of how it would consume the increased volume of recycled waste glass. Second, the government's action provided incentives for glass manufacturers such as Taiwan Glass to purchase recycled glass as their input materials. Glass manufacturers were forced to place a deposit in a government fund, which could be redeemed if the glass manufacturer used recycled glass as its input. In sum, the government's policy has changed the mechanisms by which the leading firm trades with different stakeholders.

\section{Conclusions}

This research has identified a set of mechanisms by which the leading glass-recycling firm in Taiwan governs its ecosystem. First, continuous value capture is important for the leading firm as the demand and supply of waste glass are mostly unbalanced. Second, the entrepreneur's social network has been found to have influenced his business's development throughout its ecosystem's lifecycle. Third, brand image and CSR have influenced the company's relationships with its stakeholders, acting as an invisible force that binds their connections. Moreover, the company's capabilities in the recycling process determine its costs and quality, which are critical factors to surviving in the glass recycling 
industry (due to its low margins). Finally, we have also observed that government policy has had a huge impact in reframing the relationships between the various stakeholders.

Theoretically and practically, this research makes several contributions. First, to our understanding, we believe we are breaking new ground in seeking to link the concepts of the business ecosystem and the circular economy, which we believe will be an important research stream in the future, embracing economic and environmental value simultaneously. Second, this research has provided evidence from a different research context than the prior literature. Most research on business ecosystems has focused on (high-margin, profit-driven) industries such as information and communication technology, automobiles, and retail. This research provides a different perspective, investigating how a leading firm governs its ecosystem under low-margin conditions. Finally, as Taiwan is also a pioneer of the circular economy in Asia, this research provides an informative case study illustrating how the leading firm in the recycling ecosystem has adjusted to (1) a new government policy and (2) an increase in silicon-related waste due to regional development. These lessons could also be valuable for the future development of the Southeast Asian countries.

In spite of the rigorous research methods, the case mainly concerns the glass recycling industry alone, which will limit its generalizability to other industries. Future research could be conducted in other recycling industries, as different recycling ecosystems will likely have their own characteristics (related to the recycled materials). We also suggest that future research should seek further opportunities for linking business ecosystem and circular economy research.

Acknowledgments: The authors gratefully acknowledge Chun-Tzu Wu and Ting-An Wu from Spring Pool Glass who supported this research by providing access to their company, as well as sharing their experience and knowledge.

Author Contributions: Ying-Che Hsieh designed this study, carried out the empirical work, wrote the literature review, and drafted the manuscript. Kuo-Yi Lin participated in the empirical studies and helped to draft the literature review. Chao Lu and Ke Rong participated in the design of the study and the data analysis. All authors read and approved the final manuscript.

Conflicts of Interest: The authors declare no conflict of interest.

\section{Appendix A}

Table A1. Glass recycling ecosystem interview list.

\begin{tabular}{cccccc}
\hline Company & Location & Types of Business & Interviewee's Position & Method & Duration \\
\hline Spring Pool Glass & Hsinchu & Leading firm & Chairman/founder & Interview & $4 \mathrm{~h}$ \\
Spring Pool Glass & Hsinchu & Leading firm & CEO & Site visit, interview & $3 \mathrm{~h}$ \\
Spring Pool Glass & Hsinchu & Leading firm & Factory director & Site visit, interview & $3 \mathrm{~h}$ \\
Spring Pool Glass & Hsinchu & Leading firm & Two senior glass artists & Site visit, interview & $2 \mathrm{~h}$ \\
Spring Pool Glass & Hsinchu & Leading firm & Specialist & Interview & $3 \mathrm{~h}$ \\
Spring Pool Glass & Hsinchu & Leading firm & Specialist & Interview & $3 \mathrm{~h}$ \\
Spring Pool Glass & Hsinchu & Leading firm & Specialist & Interview & $3 \mathrm{~h}$ \\
Spring Pool Glass & Taichung & Leading firm & Specialist & Phone call & $1 \mathrm{~h}$ \\
Spring Pool Glass & Miaoli & Leading firm & Specialist & Interview & $2 \mathrm{~h}$ \\
Company A & Hsinchu & Waste glass supplier & Director & Interview & $2 \mathrm{~h}$ \\
Company A & Hsinchu & Waste glass supplier & Director & Interview & $2 \mathrm{~h}$ \\
Company A & Hsinchu & Waste glass supplier & Director & Interview & $2 \mathrm{~h}$ \\
\hline
\end{tabular}

\section{References}

1. Moore, J.F. Predators and prey: A new ecology of competition. Harv. Bus. Rev. 1993, 71, 75-83. [CrossRef] [PubMed]

2. Basole, R.C.; Karla, J. On the evolution of mobile platform ecosystem structure and strategy. Bus. Inf. Syst. Eng. 2011, 3. [CrossRef]

3. Ceccagnoli, M.; Forman, C.; Huang, P.; Wu, D.J. Cocreation of value in a platform ecosystem: The case of enterprise software. Manag. Inf. Syst. Q. 2012, 36, 263-290.

4. Adner, R. Match your innovation strategy to your innovation ecosystem. Harv. Bus. Rev. 2006, 84, 98-107. [PubMed] 
5. Carayannis, E.G.; Campbell, D.F. 'Mode 3' and 'Quadruple Helix': Toward a 21st century fractal innovation ecosystem. Int. J. Technol. Manag. 2009, 46, 201-234. [CrossRef]

6. Rohrbeck, R.; Hölzle, K.; Gemünden, H.G. Opening up for competitive advantage-How Deutsche Telekom creates an open innovation ecosystem. $R$ D Manag. 2009, 39, 420-430. [CrossRef]

7. Shi, X.; Shi, Y. Conceptualizing Entrepreneurial Ecosystems: Definition, Configurations and Health. Acad. Manag. Proc. 2016. [CrossRef]

8. Rong, K.; Shi, Y. Business Ecosystems: Constructs, Configurations, and the Nurturing Process; Palgrave Macmillan: London, UK, 2014.

9. Li, Y.R. The technological roadmap of Cisco's business ecosystem. Technovation 2009, 29, 379-386. [CrossRef]

10. Gregson, N.; Crang, M.; Fuller, S.; Holmes, H. Interrogating the circular economy: The moral economy of resource recovery in the EU. Econ. Soc. 2015, 44, 218-243. [CrossRef]

11. Taiwan: The World's Geniuses of Garbage Disposal. Available online: http://www.wsj.com/articles/ taiwan-the-worlds-geniuses-of-garbage-disposal-1463519134 (accessed on 7 May 2017).

12. Recycling Discarded Glass Bottles Provide New Surprise! Available online: https:/ / greenliving.epa.gov.tw / GreenLife/webNewsZone/ShowNews.aspx?newsid=13400 (accessed on 7 May 2017).

13. New Recycling Technology for Discarded Liquid Crystal Display Creates Green Economic Prosperity. Available online: https://greenliving.epa.gov.tw/GreenLife/webNewsZone/ShowNews.aspx?newsid= 12619 (accessed on 7 May 2017).

14. Moore, J.F. The Death of Competition: Leadership and Strategy in the Age of Business Ecosystems; Harper Paperbacks: New York, NY, USA, 1996.

15. Yun, J.J.; Won, D.; Jeong, E.; Park, K.; Yang, J.; Park, J. The relationship between technology, business model, and market in autonomous car and intelligent robot industries. Technol. Forecast. Soc. Chang. 2016, 103, 142-155. [CrossRef]

16. Iansiti, M.; Levien, R. Strategy as ecology. Harv. Bus. Rev. 2004, 82, 68-81. [PubMed]

17. Rong, K.; Lin, Y.; Shi, Y.; Yu, J. Linking business ecosystem lifecycle with platform strategy: A triple view of technology, application and organisation. Int. J. Technol. Manag. 2013, 62, 75-94. [CrossRef]

18. Rong, K.; Hu, G.; Lin, Y.; Shi, Y.; Guo, L. Understanding business ecosystem using a 6C framework in Internet-of-Things-based sectors. Int. J. Prod. Econ. 2015, 159, 41-55. [CrossRef]

19. Clarysse, B.; Wright, M.; Bruneel, J.; Mahajan, A. Creating value in ecosystems: Crossing the chasm between knowledge and business ecosystems. Res. Policy 2014, 43, 1164-1176. [CrossRef]

20. Gawer, A.; Cusumano, M.A. Industry platforms and ecosystem innovation. J. Prod. Innov. Manag. 2014, 31, 417-433. [CrossRef]

21. De Vasconcelos Gomes, L.A.; Facin, A.L.F.; Salerno, M.S.; Ikenami, R.K. Unpacking the innovation ecosystem construct: Evolution, gaps and trends. Technol. Forecast. Soc. Chang. 2016. [CrossRef]

22. Adner, R.; Kapoor, R. Value creation in innovation ecosystems: How the structure of technological interdependence affects firm performance in new technology generations. Strateg. Manag. J. 2010, 31, 306-333. [CrossRef]

23. Adner, R.; Kapoor, R. Innovation ecosystems and the pace of substitution: Re-examining technology S-curves. Strateg. Manag. J. 2016, 37, 625-648. [CrossRef]

24. Nambisan, S.; Baron, R.A. Entrepreneurship in Innovation Ecosystems: Entrepreneurs' Self-Regulatory Processes and Their Implications for New Venture Success. Entrep. Theory Pract. 2013, 37, 1071-1097. [CrossRef]

25. Rong, K.; Wu, J.; Shi, Y.; Guo, L. Nurturing business ecosystems for growth in a foreign market: Incubating, identifying and integrating stakeholders. J. Int. Manag. 2015, 21, 293-308. [CrossRef]

26. Adner, R. Ecosystem as Structure: An Actionable Construct for Strategy. J. Manag. 2017, 43, 39-58. [CrossRef]

27. Iansiti, M.; Richards, G.L. The information technology ecosystem: Structure, health, and performance. Antitrust Bull. 2006, 51, 77-110. [CrossRef]

28. Williamson, P.J.; De Meyer, A. Ecosystem advantage. Calif. Manag. Rev. 2012, 55, 24-46. [CrossRef]

29. Lu, C.; Rong, K.; You, J.; Shi, Y. Business ecosystem and stakeholders' role transformation: Evidence from Chinese emerging electric vehicle industry. Expert Syst. Appl. 2014, 41, 4579-4595. [CrossRef]

30. Winans, K.; Kendall, A.; Deng, H. The history and current applications of the circular economy concept. Renew. Sustain. Energy Rev. 2017, 68, 825-833. [CrossRef] 
31. Ness, D. Sustainable urban infrastructure in China: Towards a factor 10 improvement in resource productivity through integrated infrastructure systems. Int. J. Sustain. Dev. World Ecol. 2008, 15, 288-301.

32. Ghisellini, P.; Cialani, C.; Ulgiati, S. A review on circular economy: The expected transition to a balanced interplay of environmental and economic systems. J. Clean. Prod. 2016, 114, 11-32. [CrossRef]

33. Su, B.; Heshmati, A.; Geng, Y.; Yu, X. A review of the circular economy in China: Moving from rhetoric to implementation. J. Clean. Prod. 2013, 42, 215-227. [CrossRef]

34. Zhu, D.J.; Qiu, S.F. Analytical tool for urban circular economy planning and its preliminary application: A case of Shanghai. City Plan. Rev. 2007, 31, 64-69.

35. Yin, R.K. Case Study Research: Design and Methods; Sage Publications: London, UK, 2013.

36. Lu, I.Y.; Kuo, T.; Lin, T.S.; Tzeng, G.H.; Huang, S.L. Multicriteria decision analysis to develop effective sustainable development strategies for enhancing competitive advantages: Case of the TFT-LCD industry in Taiwan. Sustainability 2016, 8, 646. [CrossRef]

37. How Does Hong Kong Compare with Other Countries for Glass Recycling? Available online: http://www. greenglass.org.hk/en/?p=43 (accessed on 7 May 2017).

38. Eisenhardt, K.M. Better stories and better constructs: The case for rigor and comparative logic. Acad. Manag. Rev. 1991, 16, 620-627.

39. Dyer, W.G.; Wilkins, A.L. Better stories, not better constructs, to generate better theory: A rejoinder to Eisenhardt. Acad. Manag. Rev. 1991, 16, 613-619.

40. Eisenhardt, K.M. Building theories from case study research. Acad. Manag. Rev. 1989, 14, 532-550.

41. Haynie, A.; Huntington, H. Strong connections, loose coupling: The influence of the Bering Sea ecosystem on commercial fisheries and subsistence harvests in Alaska. Ecol. Soc. 2016, 21, 6. [CrossRef]

(C) 2017 by the authors. Licensee MDPI, Basel, Switzerland. This article is an open access article distributed under the terms and conditions of the Creative Commons Attribution (CC BY) license (http:/ / creativecommons.org/licenses/by/4.0/). 